\title{
Cerebral Venous Thrombosis: Risk Factors, Possible Etiologies and Outcome
}

\author{
MONA H. DEWIDAR, M.Sc.*; MOHAMMED ADEL EL-TOMEY, M.D.**; WAEL AHMED FADEL, M.D.* and \\ TAREK MOHAMMED EL-GAMMAL, M.D.*
}

The Departments of Neuropsychiatry* and Diagnostic Radiology**, Faculty of Medicine, Tanta University

\begin{abstract}
Background: CVT represented $1 \%$ of all strokes. The most frequent risk factors associated conditions for CVT are genetic prothrombotic conditions, antiphospholipid syndrome and other acquired prothrombotic diseases, including cancer, oral contraceptives, puerperium and pregnancy, infections and trauma.
\end{abstract}

Aim of the Work: Is to study possible etiologies, risk factors, clinical presentations, radiological features and outcome of cerebral venous thrombosis during child bearing period.

Patients and Methods: This study was conducted in the Neuropsychiatric Department Tanta University Hospital on 82 patients with CVT, aged from $15-45$ years. They were classified into female and male groups plus 20 control group matched with age. All patients were subjected to full history taking, neurologic examination including evaluation by Glasgow coma scale (GCS) and National Institute of Health Stroke Scale (NIHSS), laboratory investigations, neuroimaging including: CT, MRI, MRV were done and follow-up by Modified Rankin Scale (MRS) after 3 months.

Results: OCP was the most common risk factor followed by postpartum state. Single risk factor was presented in $48.8 \%$ and multiple risk factors were presented in $22 \%$. Headache was the most common presenting symptoms followed by GTCS and motor deficit. Headache, GTCS, motor deficit and encephalopathy were more in females while papilledema, focal seizures, sensory deficit and aphasia were more in males. Hypercoagulable state was the most common etiology followed by antiphospholipid syndrome and SLE. Hypercoagulable state was most common in both sex, while sepsis and Behcet were significantly more common in males. Superior sagittal sinus (SSS) was the most common affected sinus followed by transverse and sigmoid sinuses. Single affected sinus was in $65.9 \%$, while multiple affected sinuses was in $31.7 \%$ of patients. 12 patients $(14.6 \%)$ were died. The most common cause of death was herniation followed by uncontrolled seizures. Factors associated with poor outcome were GCS less than 10 and NIHSS more than 14 .

Conclusion: Headache is the most common presenting symptoms followed by motor deficit. D-dimer is positive in

Correspondence to: Dr. Mona Hassan Dewidar, The Departments of Neuropsychiatry, Faculty of Medicine, Tanta University
$76 \%$. Hypercoagulable state is the most common etiology followed by antiphospholipid syndrome and SLE. SSS is the most common affected sinus then transverse sinus and sigmoid one. Female sex, GCS less than 10, NIHSS more than 14 and patients presented by headache have poor outcome.

Key Words: CVT-Etiology-Risk factors-Outcome.

\section{Introduction}

CEREBRAL venous thrombosis (CVT) is a stroke type that is caused by thrombus in $\geq 1$ of the venous sinuses and manifests primarily as headache. CVT makes up $0.5 \%$ to $1 \%$ of all strokes, but is the stroke type that shows the most prominent differential sex prevalence. In adulthood, the majority of affected individuals are women [1]

CVT is caused by systemic or local imbalances in pro-thrombotic and thrombolytic processes. As venous blood is forced back into small vessels and capillaries, an increase in venous and capillary pressure occurs, disruption of the blood brain barrier and decrease in cerebral perfusion pressure develops, which leads to cerebral oedema, local ischaemia and often intracerebral haemorrhage [2]

Pregnancy and the puerperium period are times of increased risk for venous thrombosis for women, including CVT. The greatest risk periods for CVT include the third trimester and the first 4 postpartum weeks. Cesarean delivery appears to be associated with a higher risk of CVT after adjustment for age, vascular risk factors, presence of infections, hospital type, and location [3]

The clinical presentation of cerebral venous thrombosis can be highly variable. Onset of symptoms and signs may be acute, subacute or chronic. Four major syndromes have been described: Isolated intracranial hypertension, Focal neurological abnormalities, Seizures and Encephalopathy [4] . 
Diagnostic modalities currently used for the confirmation of CVT include computed tomography (CT), magnetic resonance imaging (MRI), and cerebral angiography. Current recommendations incorporate venographic imaging in any case with clinically suspected CVT even with initially negative CT or MRI [5]

Cerebral venous thrombosis usually has a good prognosis, but can result in death or permanent disability. The main cause of death with acute CVT is transtentorial herniation secondary to a large hemorrhagic lesion. Status epilepticus, medical complications, and pulmonary embolism are among the other causes of early death [6].

Aim of the work: Is to study possible etiologies, risk factors, clinical presentations, radiological features and outcome of cerebral venous thrombosis during child bearing period.

\section{Patients and Methods}

This study was conducted in the Neuropsychiatry Department of Tanta University Hospital on 82 patients of cerebral venous thrombosis (CVT) in the period between December 2015 and December 2016. They were classified into female group (66 patients) and male group (16 patients). Possible risk factors and etiologies of CVT were assessed through either imaging or laboratory studies. Our patients were subjected to follow-up after three months of admission date including evaluation of their clinical and functional outcome using Modified Rankin Disability Scale.

Each patient was subjected to full history taking, thorough neurological examination including GCS and NIHSS, brain CT, MRI and MRV. CT brain was done to 74 patients excluding pregnant patients and MRI brain and MRV were done to 82 patients. Routine laboratory investigations including ESR, CRP, liver functions, renal functions, blood picture and Triglycerides. Specific laboratory investigations including D-dimer, ANA, anti-double strand DNA, anticardiolipin antibodies, lupus anticoagulant, antiphospholipid antibodies and thrombophilia testing.

\section{Results}

The mean age of males was higher than females, but without significant difference. $75 \%$ of males were from rural area versus $60.6 \%$ for females. The mean hospital stay of females was higher than males, but without significant difference (Table $1)$.
Table (1): Demographic data of female versus male

\begin{tabular}{lcccc}
\hline & $\begin{array}{c}\text { Female } \\
(\mathrm{n}=66)\end{array}$ & $\begin{array}{c}\text { Male } \\
(\mathrm{n}=16)\end{array}$ & $\begin{array}{c}\text { Test } \\
\text { of sig. }\end{array}$ & $\begin{array}{c}p \text { - } \\
\text { value }\end{array}$ \\
\hline $\begin{array}{c}\text { Age: } \\
\text { (mean } \pm \mathrm{SD})\end{array}$ & $30.272 \pm 7.74$ & $32.62 \pm 8.89$ & $t=0.85$ & 0.39 \\
$\begin{array}{c}\text { Residency } \\
(n, \%):\end{array}$ & & & & \\
$\quad \begin{array}{l}\text { Rural } \\
\text { Urban }\end{array}$ & $40(60.6)$ & $\begin{array}{l}12(75.0) \\
6(25.0)\end{array}$ & $\chi^{2}=0.10$ & 0.28 \\
$\begin{array}{c}\text { Hospital stay } \\
\text { (mean } \pm \text { SD) }\end{array}$ & $6.81 \pm 3.06$ & $6.25 \pm 2.04$ & $\mathrm{U}=0.30$ & 0.75 \\
\hline
\end{tabular}

Oral contraceptive pills was the most common risk factor $(42.4 \%)$ followed by postpartum state (33.3\%), pregnancy (12.2\%), abortion (12.1\%), smoking (7.3) and addiction, DM, HTN (4.9\%) and past history of DVT (2.4\%). The risk factors of significance were OCP and postpartum state. $48 \%$ of patients had one risk factor, $22 \%$ had multiple risk factors and $29.3 \%$ did not have any risk factor (Table 2).

Table (2): Possible risk factors among CVT patients.

\begin{tabular}{|c|c|c|c|c|}
\hline & \multicolumn{2}{|c|}{ CVT $(n=82)$} & \multirow{2}{*}{$\begin{array}{l}\text { Test } \\
\text { of sig. }\end{array}$} & \multirow{2}{*}{$p$-value } \\
\hline & No. & $\%$ & & \\
\hline \multicolumn{5}{|l|}{$\begin{array}{l}\text { Gender specific } \\
\text { risk factors }(N=66) \text { : }\end{array}$} \\
\hline Pregnancy & 8 & 12.1 & $\mathrm{FE}=0.99$ & 0.31 \\
\hline $\mathrm{OCP}$ & 28 & 42.4 & $\chi^{z}=10.30$ & $0.001 *$ \\
\hline Postpartum state & 22 & 33.3 & $\tilde{\mathrm{FE}}=5.69$ & $0.01 *$ \\
\hline Abortion & 8 & 12.1 & $\mathrm{FE}=0.99$ & 0.31 \\
\hline Addiction & 4 & 4.9 & $\mathrm{FE}=0.13$ & 0.71 \\
\hline Smoking & 6 & 7.3 & $\mathrm{FE}=0.01$ & 0.92 \\
\hline \multicolumn{5}{|l|}{ Comorbidity: } \\
\hline No & 72 & 87.8 & & \\
\hline HTN & 4 & 4.9 & & \\
\hline $\mathrm{DM}$ & 4 & 4.9 & & \\
\hline DVT & 2 & 2.4 & & \\
\hline
\end{tabular}

Headache, GTCS, motor deficit and encephalopathy were more common in females while papilledema, focal seizures, sensory deficit and aphasia were more in males, but only GTCS showed significant difference more in females versus males $(45.5 \%, 0 \%)$ and focal seizures showed significant difference more in males versus females $(12.5 \%, 0 \%)$ (Table 3 ).

Behcet was present in $12.5 \%$ in males and $0.0 \%$ in females and the difference was statistically significant ( $p$-value 0.04 ). Sepsis was present in $25 \%$ of males and $0 \%$ of females and the difference was statistically significant (Fig. 1).

Cord sign was presented in $18.2 \%$ of females and $37.5 \%$ of males in CT and in $21.2 \%$ and $12.5 \%$ in MRI. Empty delta sign was presented in $33.3 \%$ of females and $37.5 \%$ of males. Parenchymal lesions were presented in $9.1 \%$ in females in CT and $51.5 \%$ in MRI. All neuroradiology parameter showed non- 
significant difference except for normal MRI $(p=0.007)$ which was significant more in males. (Table 4).

The most common sinus affected was SSS (65.9\%) followed by transverse sinus $(43.9 \%)$ and sigmoid sinus $(17 \%)$. The least affected sinus was dural sinus (4.9\%). single sinus affected was in $65.9 \%$ and multiple affected sinuses were in $31.7 \%$ of patients (Fig. 2).

$85 \%$ of patients were survived. $94.1 \%$ showed complete improvement, while $14.6 \%$ were dead. $87.9 \%$ of females and $75 \%$ of males were survived $.89 .7 \%$ of females and $12 \%$ of males showed complete recovery. 8 females $(12.1 \%)$ and 4 males $(25 \%)$ were died with no significance regarding morbidity and mortality in both sexes (Table 5).

There was statistically significant relationship between hypercoagulable state and mortality ( $p=$ 0.004 ) while sepsis, SLE, antiphospholipid syndrome and Behcet had non-significant relation with outcome (Table 6).

All risk factors showed no significant relationship with morbidity and mortality (Table 7).

Table (3): Clinical pictures of CVT female versus male patients.

\begin{tabular}{|c|c|c|c|c|c|c|}
\hline & \multicolumn{2}{|c|}{$\begin{array}{c}\text { Females } \\
(n=66)\end{array}$} & \multicolumn{2}{|c|}{$\begin{array}{l}\text { Males } \\
(\mathrm{n}=16)\end{array}$} & \multirow[b]{2}{*}{ Lest } & \multirow{2}{*}{$\begin{array}{c}p- \\
\text { value }\end{array}$} \\
\hline & No. & $\% \mathrm{I}$ & No. & $\%$ & & \\
\hline \multicolumn{7}{|l|}{ Isolated ICT: } \\
\hline Headache & 48 & 72.7 & 10 & 62.5 & 0.25 & 0.61 \\
\hline Papilledema & 20 & 30.3 & 8 & 50.0 & $X^{2}=2.22$ & 0.13 \\
\hline \multicolumn{7}{|l|}{ Seizures: } \\
\hline GTC seizures & 30 & 45.5 & 0 & 0.0 & $X^{2}=11.46$ & $0.001 *$ \\
\hline Focal seizures & 0 & 0.0 & 2 & 12.5 & 4.02 & $0.04 *$ \\
\hline \multicolumn{7}{|l|}{ Focal deficit: } \\
\hline Motor deficit & 28 & 42.4 & 4 & 25.0 & $X^{2}=1.64$ & 0.20 \\
\hline Sensory deficit & 4 & 6.1 & 2 & 12.5 & 0.12 & 0.72 \\
\hline Aphasia & 2 & 13.0 & 2 & 12.5 & 0.87 & 0.35 \\
\hline Encephalopathy & 6 & 9.1 & 2 & 12.5 & 0.00 & 0.95 \\
\hline
\end{tabular}

Table (4): Radiological features among CVT patients

\begin{tabular}{|c|c|c|c|c|c|c|}
\hline & \multicolumn{2}{|c|}{$\begin{array}{c}\text { Females } \\
(\mathrm{n}=66)\end{array}$} & \multicolumn{2}{|c|}{$\begin{array}{l}\text { Males } \\
(\mathrm{n}=16)\end{array}$} & \multirow{2}{*}{$\begin{array}{c}\text { Fisher's } \\
\text { Exact } \\
\text { test }\end{array}$} & \multirow{2}{*}{$\begin{array}{c}p- \\
\text { value }\end{array}$} \\
\hline & No. & $\% \mathrm{I}$ & No. & $\%$ & & \\
\hline \multicolumn{7}{|l|}{$C T(n=74):$} \\
\hline Normal & 14 & 21.1 & 4 & 25.0 & 0.00 & 0.99 \\
\hline Edema & 32 & 48.5 & 8 & 50.0 & 0.01 & 0.91 \\
\hline Cord sign & 12 & 18.2 & 6 & 37.5 & 1.79 & 0.18 \\
\hline $\begin{array}{l}\text { Parenchymal } \\
\text { lesion }\end{array}$ & 6 & 9.1 & 2 & 12.5 & 0.00 & 0.95 \\
\hline Not done & & & & & & \\
\hline \multicolumn{7}{|l|}{$M R I(n=82):$} \\
\hline Normal & 10 & 15.2 & 8 & 50.0 & 7.21 & $0.007 *$ \\
\hline Cord sign & 14 & 21.2 & 2 & 12.5 & 0.19 & 0.66 \\
\hline Empty delta sign & 22 & 33.3 & 6 & 37.5 & 0.00 & 0.75 \\
\hline $\begin{array}{l}\text { Parenchymal } \\
\text { lesion }\end{array}$ & 34 & 51.5 & 4 & 25.0 & 3.64 & 0.056 \\
\hline \multicolumn{7}{|l|}{$M R V(n=82)$} \\
\hline Normal & 2 & 3.0 & 2 & 12.5 & 0.687 & 0.35 \\
\hline Abnormal & 64 & 97.0 & 14 & 87.5 & & \\
\hline
\end{tabular}

Table (5): Outcome among CVT patients.

\begin{tabular}{|c|c|c|c|c|c|c|}
\hline & \multicolumn{2}{|c|}{$\begin{array}{c}\text { Females } \\
(\mathrm{n}=66)\end{array}$} & \multicolumn{2}{|c|}{$\begin{array}{l}\text { Males } \\
(\mathrm{n}=16)\end{array}$} & \multirow{2}{*}{$\begin{array}{c}\text { Fisher's } \\
\text { Exact } \\
\text { test }\end{array}$} & \multirow{2}{*}{$\begin{array}{c}p- \\
\text { value }\end{array}$} \\
\hline & No. & $\%$ & No. & $\%$ & & \\
\hline \multicolumn{7}{|l|}{ Morbidity: } \\
\hline $\begin{array}{l}\text { Total impro- } \\
\text { vement }\end{array}$ & 52 & 89.7 & 12 & 100. & 0.36 & 0.54 \\
\hline $\begin{array}{l}\text { Survived } \\
\text { with death }\end{array}$ & 6 & 10.3 & 0 & 0.0 & 0.36 & \\
\hline \multicolumn{7}{|l|}{ Mortality: } \\
\hline Died & 8 & 12.1 & 4 & 25.0 & 0.43 & 0.51 \\
\hline
\end{tabular}

Table (6): Relationship between possible etiology and outcome.

\begin{tabular}{lccccc}
\hline \multicolumn{2}{c}{ Morbidity } & \multicolumn{3}{c}{ Mortality } \\
& $\begin{array}{c}\text { Total Improvement } \\
(\mathrm{n}=64) \\
\text { No. (\%) }\end{array}$ & $\begin{array}{c}\text { Improved with } \\
\text { deficit (n=6) } \\
\text { No. (\%) }\end{array}$ & $\begin{array}{c}\text { p-value Died (n=12) } \\
\text { No. (\%) }\end{array}$ & $p$-value \\
& & & & & \\
Hypercoagulable state & $42(56.3)$ & $4(66.7)$ & 0.95 & $2(16.7)$ & 0.004 \\
Local infection & $2(3.1)$ & $0(0.0)$ & 0.39 & $2(16.7)$ & 0.18 \\
Not detected & $4(6.3)$ & $2(33.3)$ & 0.13 & $2(16.7)$ & 0.72 \\
SLE & $8(12.5)$ & $0(0.0)$ & 0.80 & $2(16.7)$ & 0.96 \\
Antiphospholipid syndrome & $6(9.4)$ & $0(0.0)$ & 0.98 & $4(33.3)$ & 0.052 \\
Behcet & $2(3.1)$ & $0(0.0)$ & 0.85 & $0(0.0)$ & 0.68 \\
Malignancy & $0(0.0)$ & $0(0.0)$ & - & $0(0.0)$ & \\
\hline
\end{tabular}


Table (7): Relationship between possible etiology and outcome.

\begin{tabular}{lccccc}
\hline & \multicolumn{3}{c}{ Morbidity } & & \multicolumn{2}{c}{ Mortality } \\
\cline { 2 - 3 } & $\begin{array}{c}\text { Total Improvement } \\
(\mathrm{n}=64) \\
\text { No. (\%) }\end{array}$ & $\begin{array}{c}\text { Improved with } \\
\text { deficit (n=6) } \\
\text { No. (\%) }\end{array}$ & $p$-value & $\begin{array}{c}\text { Died (n=12) } \\
\text { No. (\%) }\end{array}$ & $p$-value \\
\hline Pregnancy & $6(9.4)$ & $2(33.3)$ & 0.13 & $0(0.0)$ & 0.59 \\
OCP & $24(37.5)$ & $2(33.3)$ & 1.00 & $2(16.7)$ & 0.20 \\
Delivery & $18(28.1)$ & $0(0.0)$ & 0.32 & $4(33.3)$ & 0.72 \\
Addiction & $4(6.3)$ & $0(0.0)$ & 1.00 & $0(0.0)$ & 1.00 \\
Smoking & $4(6.3)$ & $0(0.0)$ & 0.53 & $2(16.7)$ & 0.21 \\
Abortion & $6(9.4)$ & $1(11.1)$ & 1.00 & $2(16.7)$ & 0.48 \\
Comorbidity: & & & & & \\
HTN & $2(3.1)$ & $0(0.0)$ & & $2(16.7)$ & \\
DM & $4(6.3)$ & $0(0.0)$ & 1.00 & $0(0.0)$ & 0.15 \\
DVT & $2(3.1)$ & $0(0.0)$ & & $0(0.0)$ & \\
\hline
\end{tabular}
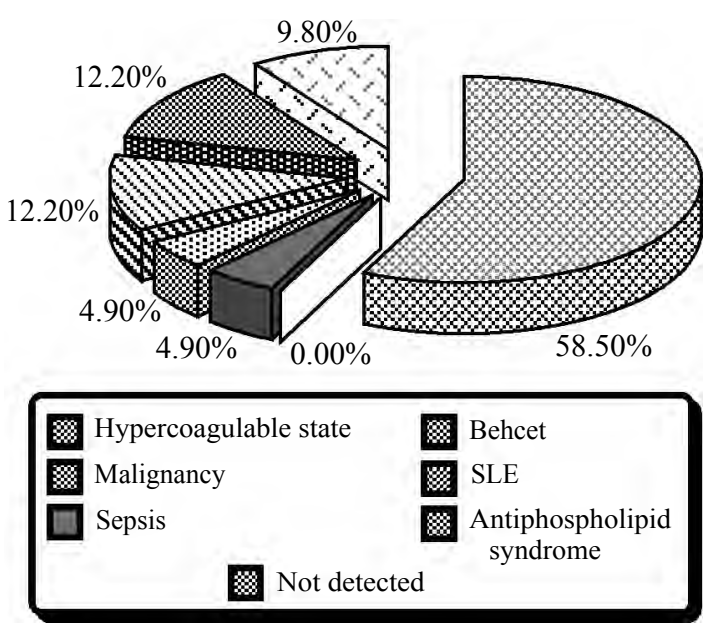

Fig. (1): Showing possible etiology among CVT patients.

\section{Discussion}

In the present study, high predominance of female involvement was noticed (80\%), that was in agreement with Souirti et al. and Irene et al. studies in which females were more affected than males, Also Zuurbier et al., stated that CVT was higher in females compared to males similar to the present study and they attributed that to the increased use of oral contraceptive pills, improved access to health care for women and increased frequency of CVT diagnosis in women [7-9] .

The mean age of our study patients was 31 years old with females being more likely to present at a younger age compared to males and that was in accordance to Lim et al., study in which the mean age of females to males ( 33 versus 45 years), this could be attributed to the higher incidence of CVT among females during child bearing period [10].

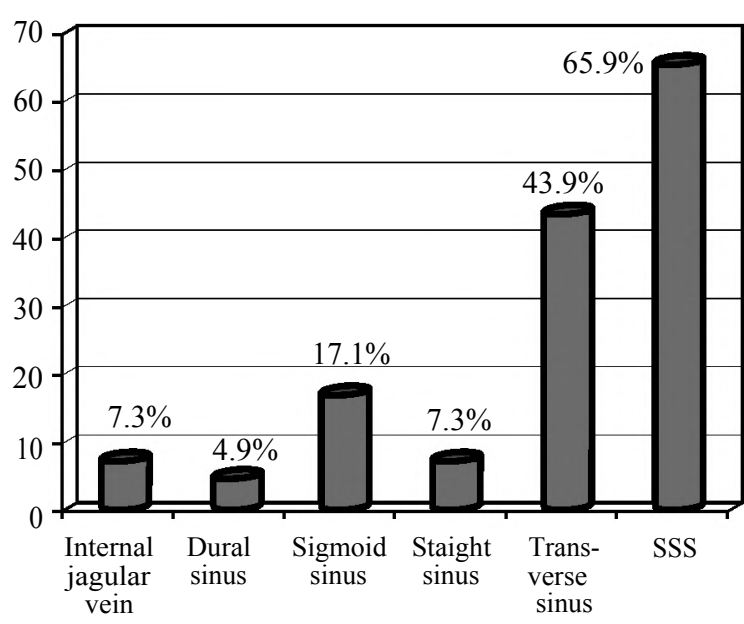

Fig. (2): Showing affected sinuses in CVT patients.

Coutinhlo et al. stated that women had a better prognosis than men (complete recovery $81 \%$ versus $71 \%$ ), while in our study $100 \%$ of men showed complete recovery versus $89.7 \%$ of women, which is mostly due to the lower spectrum of age in the current study (15-45) compared to the previous study, in which increase age of poor prognosis due to increased risk of malignancy and infections in older age [11]

In addition to the variation in clinical presentations, the etiology of CVT is commonly multifactorial, with a large portion of patients having more than one cause or predisposing factor. OCP was the most common gender specific risk factors $42.4 \%$, that was in agreement with Terazzi et al., Ferro et al. and Dentali et al., [12-14] .

Coutinhlo et al., postulated that hypercoagulable state was more or less similar in females and males ( $22 \%$ versus $25 \%$ ). Infections were less common among males ( $10 \%$ versus $21 \%$, while in our study, the incidence of hypercoagulable state was much 
higher in females compared to males $(63.6 \%$ versus $37.5 \%$ ), because of the increase frequency of coagulopathy in pregnant, post-partum and females taking oral contraceptive pills. and infection was in $25 \%$ of men, but not detected in women in the present study [11]

In the present study there was non-significant relationship between gender specific risk factors and outcome, while in Patil et al., and Duman et al., studies, gender specific risk factors such as puerperium and oral contraceptive use had favorable outcome. Favorable outcome in gender specific risk factors in CVT has been attributed to that occlusion is limited and transient with rapid recanalization or by development of collaterals $[15,16]$

According to VENOST study, headache was more common in males while seizures, focal deficit and encephalopathy were common in females. In our study encephalopathy, focal seizures, focal sensory deficit and papilledema were more common in males and headache, GTCs, motot deficit were common in females, which is attributed to the larger sample size in that study (1144 patients). Females were sensitive to pain and it could be expressed emotionally in females than males [16]

In the present study, headache showed significant relationship with poor outcome, while GTCs, motor deficit and encephalopathy showed nonsignificant relationship with poor outcome. Mohapatra et al. and Duman et al. studies found that focal motor deficit and encephalopathy had a poor outcome. Focal Seizures had no effect on outcome in our study similar to Duman et al., [16,17]

According to our study SSS was the most common affected sinus $65.9 \%$ followed by transverse sinus $43.9 \%$ that was in agreement with Mangshetty $\&$ Reddy study. Superficial cortical veins drain into SSS against the blood flow in the sinus, thus causing turbulence in the blood stream that is further aggravated by the presence of fibrous septa at the inferior angle of the sinus. This fact explains greater prevalence of SSS thrombosis $[\mathbf{1 8 , 1 9 ]}$

In our study $31 \%$ cases had more than one sinus involved that was in agreement with Bousser \& Barnett study who found that $40 \%$ of cases had more than one sinus was involved. That means that CVT presenting symptoms were non-specific as lead to delay in diagnosis [20].

Ferro et al., stated that ICH on admission CT is associated with poor outcome, that was not obvious in our study mostly due to small sample size and early admission with mild presentations.
Hemorrhage and infarction tend to occur more frequently in the patients with eventually poor outcome, but without significant difference similar to the present study $[\mathbf{1 3 , 2 1 ]}$.

According to Souirti et al., study, $60 \%$ of patients showed full recovery, $26 \%$ had sequelae and $10 \%$ were died while in our study $91 \%$ showed complete recovery, $8.6 \%$ had sequelae and $14.6 \%$ were died. The most common cause of death in our study was herniation (50\%). According to Alonso et al., study, death was due to malignancy and infection, that difference because of wide spectrum use of antibiotics and the wide age spectrum of other study $[\mathbf{7 , 2 2 ]}$

\section{Conclusion:}

CVT is more common in females than males. OCP and postpartum state are most common risk factors of CVT patients. Headache is the most common presenting symptoms followed by motor deficit. Motor deficit and encephalopathy are more common in females while papilledema, focal seizures, sensory deficit and aphasia were more in males. D-dimer is positive in about three fourth of patients. Hypercoagulable state and antiphospholipid syndrome are more common in females and hypercoagulable and sepsis in males. The most common sinus affected is SSS followed by transverse sinus and sigmoid sinus and multiple affected sinuses are in about one third of patients. Female sex, GCS less than 10, NIHSS more than 14 and patients presented by headache have poor outcome

\section{Acknowledgments:}

This research was carried out without funding.

\section{Conflicts of interest:}

No conflicts of interest declared.

\section{Authors' Contributions.}

All authors had equal role in design, work, statistical analysis and manuscript writing. All authors have approved the final article work.

\section{References}

1- STAR M. and FLASTER M.: "Advances and controversies in the management of cerebral venous thrombosis". Neurol Clin., 31: 765-783, 2013.

2- ROTTGER C., et al.: "A new model of reversible sinus sagittalis superior thrombosis in the rat: Magnetic resonance imaging changes". Neurosurgery, 57: 573-580, 2005.

3- BUSHNELL C., MCCULLOUGH L.D., AWAD I.A., CHIREAU M.V., et al.: "Guidelines for the prevention of stroke in women: " A statement for healthcare professionals from the American Heart Association/American Stroke Association. National Guideline Clearing house. 
Available at http:// guideline. gov/ content. aspx?i d=47871 $\&$ search $=$ cerebral+venous+ thrombosis. Accessed: November, 21, 2014.

4- PIAZZA G.: "Cerebral venous thrombosis". Circulation, 125: 1704-9, 2012.

5- SAPOSNIK G., BARINAGARREMENTERIA F., BROWN R., et al.: "Diagnosis and management of cerebral venous thrombosis": A statement for healthcare professionals from the American Heart Association/American Stroke Association. Stroke., 42 (4): 1158Y1192SN 09741143, 2011.

6- FERRO J.M., et al.: "Cerebral venous thrombosis". Presse. Med., 2016.

7- SOUIRTI Z., MESSOUAK O. and BELAHSEN F.: "Cerebral venous hrombosis: a Moroccan retrospective study of 30 cases". Pan. Afr. Med. J., 17: 281, 2014.

8- IRENE Y.L. YII , PETER J. MITCHELL, RICHARD J. DOWLING and BERNARD YAN: "Imaging predictors of clinical deterioration in cerebral venous thrombosis" Journal of Clinical Neuroscience, 19 1525-1529, 2012.

9- ZUURBIER S.M., et al.: "Clinical outcome of anticoagulant treatment in head or neck infection associated cerebral venous thrombosis". Stroke., 47: 1271-1277, 2016.

10- LIM H.Y., NG C., DONNAN G., NANDURKAR H., et al.: "Ten years of cerebral venous thrombosis: Male gender and myeloproliferative neoplasm is associated with thrombotic recurrence in unprovoked events". J. Thromb. Thrombolysis., 42: 423-31, 2016.

11-COUTINHO J., FERRO J., CANHA O.P., et al.: " Cerebral venous and sinus thrombosis in women (ISCVT)". Stroke, 40: 2356-2361, 2009.

12- TERAZZI E., MITTINO D., RUDÀ R., et al.: "Cerebral venous thrombosis: A retrospective multicentre study of 48 patients". Neurol. Sci., 25: 311-315, 2005.

13- FERRO J.M., CANHÃO P., STAM J., et al: "Investigators I. Prognosis of cerebral vein and dural sinus thrombosis: results of the International Study on Cerebral Vein and Dural Sinus Thrombosis (ISCVT)". Stroke, 35: 664-70, 2004.
14- DENTALI F., POLI D., SCODITTI U., et al.: "For the CEVETIS (Cerebral Vein thrombosis international study) Investigators. Long term outcomes of patients with cerebral vein thrombosis": A multicenter study [published correction appears in J. Thromb. Haemost., 11:399, 2013]. J. Thromb. Haemost., 10: 1297-1302, 2012.

15- VIRENDRA C. PATIL, KUSHAL CHORARIA, NEERAJ DESAI and SUMIT AGRAWAL: "Clinical profile and outcome of cerebral venous sinus thrombosis at tertiary care center" J. Neurosci. Rural. Pract. Jul-Sep., 5 (3): 218-224, 2014.

16- TASKIN DUMAN, DERYA ULUDUZ, IPEK MIDI, et al.: "A Multicenter Study of 1144 Patients with Cerebral Venous Thrombosis: The VENOST Study" Journal of Stroke and Cerebrovascular Diseases, Vol. 26, No. 8 (August), pp 1848-1857, 2017.

17- MOHAPATRA S., SWAIN B.M. and MOHANTY J. "Prognostic evaluation of cerebral venous sinus thrombosis using clinical and $\mathrm{Mr}$ sequences". J. Neurol. Neurophysiol., 5: 218. doi:10.4172/2155-9562-5-1000218, 2014.

18- BASAVARAJ MANGSHETTY and KOTTE NAGARJUNA REDDY: "Clinical and neuroimaging correlation in patients with cerebral sinus venous thrombosis" Al Ameen. J. Med. Sci., 8 (1): 64-71-US National Library of Medicine enlisted Journal-IS, 2015.

19- MUHAMMAD AZEEM UDDIN, TANVEER U.L. HAQ and MUHAMMAD ZAFAR RAFIQUE : "Cerebral Venous System Anatomy". J. Pak. Med. Assoc. Vol., 56, No. 11, November, 2006.

20- BOUSSER M.G. and BARNETT HJM: "Cerebral venous thrombosis. In: stroke: Pathophysiology, diagnosis and management". 4 th edition. New York. Churchill Livingstone, 300-21, 2004.

21- KOWOLL C.M., KAMINSKI J., WEIß V., et al.: "Severe Cerebral Venous and Sinus Thrombosis: Clinical Course, Imaging Correlates, and Prognosis". Neurocrit. Care., 25: 392-399, 2016.

22- ALONSO C-ANOVAS A., MASJUAN J., GONZ-ALEZ VALC-ARCEL J., et al.: "Cerebral venous thrombosis: when etiology makes the difference". Neurologia, 24: 439-445, 2009. 


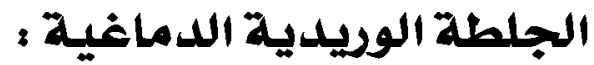

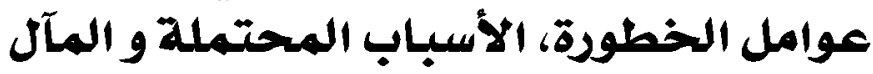

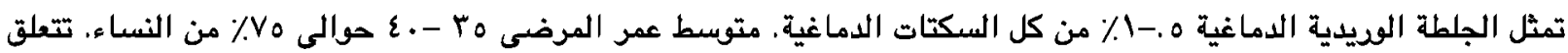

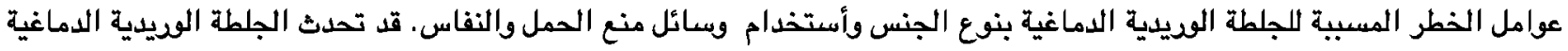

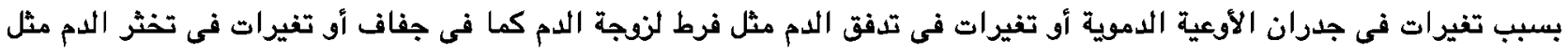

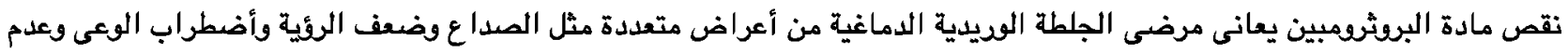
القدرة على تحريك الأطراف.

الهدف من الدراسة: إلى تقييم عوامل الخطودة والأسباب المحتملة والأعراض السريرية وكذلك المعاييرالتشخيصية المختلفة والمآل الجلطة المديدية الدماغية.

المرضى وطرق البحث: هذه الدراسة قد أجريت على المرضى الذين تم إدخالهم إلى قسم الأمراض العصبية والنفسية ويبلغ عددهم

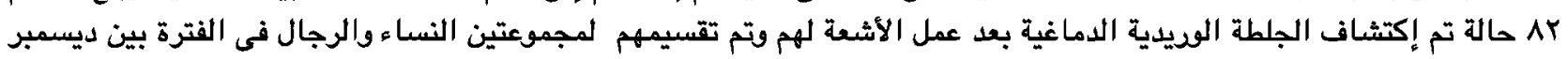

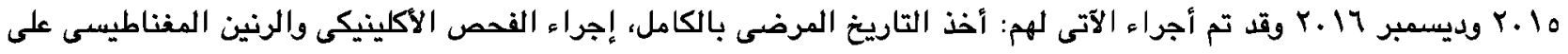

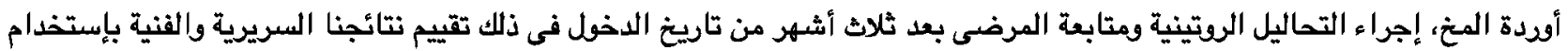
مقياس رانكين المعدل لدرجة الإعاقة.

الأستتاج: الجلطة الوديدية الدماغية أكثر شيوعاً فى النساء عن الرجال وحبوب منع الحمل وفترة ما بعد الولادة من أهم عوامل الخطوة في الجلطة الويدية.

التوصيات: نحن نوصى بضرودة عمل التحاليل اللازمة والتصوير الطبى لمعرفة إسباب الجلطة الويدية الدماغية وذلك لأخذ العلاج اللازم ومنع تكرار حدوثها. 